\title{
PRZEMÓWIENIE REKTORA POMORSKIEGO UNIWERSYTETU MEDYCZNEGO W SZCZECINIE PODCZAS INAUGURACJI ROKU AKADEMICKIEGO 2013/2014
}

\author{
ADDRESS BY THE RECTOR OF THE POMERANIAN MEDICAL UNIVERSITY \\ IN SZCZECIN INAUGURATING THE ACADEMIC YEAR OF 2013/2014
}

\begin{abstract}
Szanowni Państwo,
Pozwólcie, że pierwsze słowa skieruję do głównych bohaterów dzisiejszej uroczystości, studentów pierwszego roku. I choć zajęcia trwają już od poniedziałku, to właściwie tak naprawdę dopiero od dzisiejszego dnia rozpoczynacie ten najpiękniejszy okres waszego życia - studia. Przychodzicie na uczelnię dorośli, ale zapewniam Was, że wyjdziecie z niej dojrzali.

Dzisiejsza uroczystość to w historii naszej uczelni wydarzenie szczególne. Już za kilka tygodni, 25 listopada przypada 65. rocznica pierwszej inauguracji roku akademickiego, podczas której immatrykulowano, tzn. wciągnięto do spisu pierwszych 59 studentów nowo powstałej Akademii Lekarskiej w Szczecinie. W mieście, w którym do tego czasu nigdy, nawet w okresie działalności Pedagogium Książęcego, nie nauczano medycyny na poziomie uniwersyteckim. W kategoriach życia ludzkiego 65 lat to wiek dostojny, ale w kategoriach instytucji to zaledwie wejście w dojrzałość. Niech mi będzie więc wolno przywołać z imienia i nazwiska tych, którzy położyli fundament, na którym my, ich późniejsze uniwersyteckie wnuki i prawnuki, budujemy dzień dzisiejszy i przyszłość naszego Uniwersytetu: pierwszy rektor Jakub Węgierko, Tadeusz Chorążak, Artur Chwalibogowski, Tadeusz Markiewicz, Czesław Murczyński, Tadeusz Sokołowski, Witold Starkiewicz, Kazimierz Stojałowski, Józef Taniewski i January Zubrzycki. Wkrótce dołączyli do nich: Izabela Cwojdzińska-Gądzikiewicz, Lech Działoszyński, Adam Krechowiecki, Wanda Murczyńska, Jan Słotwiński, Eugeniusz Miętkiewski, Edward Gorzkowski, Irena Semadeni i Bolesław Górnicki.

W pierwszym roku działalności uczelni naukę podjęło 59 studentów, a dzisiaj po 65 latach wchodzimy w nowy rok akademicki z liczbą blisko 5000 studentów, w tym 605 anglojęzycznych. Na pierwszym roku studia rozpoczyna 1386 studentów, w tym 142 studentów anglojęzycznych, wśród
\end{abstract}

nich jest także 20 studentów z Niemiec, którzy podejmują studia w ramach programu Asklepios, utworzonego przez PUM z koncernem Asklepios Kliniken GmbH z Hamburga. W ramach tego programu zajęcia kliniczne dla studentów będą prowadzone w języku niemieckim w akredytowanych przez PUM szpitalach sieci Asklepios w Niemczech.

Our dear students of English Program at Medical and Dental Faculty! Be sure that the Pomeranian Medical University in Szczecin is a student-friendly school where you have the opportunity to achieve profession devoted to human health and life. Good luck!

Besonders herzlich begrüße ich die Studenten vom Asklepios Programm. Ich hoffe, daß der mythische Asklepios für Ihre Kinder sorgen wird und Sie in der Zukunft gute Aerzte werden.

Od 21 sierpnia 2010 r. jesteśmy uniwersytetem, Pomorskim Uniwersytetem Medycznym w Szczecinie. I to szlachectwo zobowiązuje. Wszak uniwersytet to ogół, społeczność nauczycieli i uczniów (łac. universitas magistrorum et scholarium), a jego zadaniem według Kazimierza Twardowskiego (twórcy filozoficznej szkoły lwowsko-warszawskiej) ,jest zdobywanie prawd i prawdopodobieństw naukowych oraz krzewienie umiejętności ich dochodzenia. Rdzeniem i jądrem pracy uniwersyteckiej jest tedy twórczość naukowa, zarówno pod względem merytorycznym, jak i pod względem metodycznym".

Takie pojmowanie roli uniwersytetu jest nam równie bliskie w XXI w. O powyższym świadczy uzyskanie przez Pomorski Uniwersytet Medyczny w Szczecinie trzeciego miejsca, zaraz za Uniwersytetem Jagiellońskim i Warszawskim, pod względem efektywności naukowej, umiędzynarodowienia oraz publikacji prac naukowych w latach 2008-2012 w prestiżowym rankingu organizowanym corocznie przez „Perspektywy” i „Rzeczpospolitą”. Na uczelni realizujemy aktualnie 59 projektów badawczych, finanso- 
wanych przez Narodowe Centrum Nauki oraz Ministerstwo Nauki i Szkolnictwa Wyższego.

W opublikowanej 30 września br. ocenie parametrycznej, dokonanej przez Komitet Ewaluacji Jednostek Naukowych, Wydział Lekarski z Oddziałem Nauczania w Języku Angielskim oraz Wydział Lekarsko-Biotechnologiczny i Medycyny Laboratoryjnej otrzymały kategorię A, potwierdzając „najwyższej próby jakość swojej pracy badawczej” (cytat z listu minister Barbary Kudryckiej), a Wydział Lekarsko-Stomatologiczny i Wydział Nauk o Zdrowiu kategorię B. Ten sukces cieszy wszystkich nas, którzy staramy się uprawiać naukę, pokazując jednocześnie obszary, w których możemy i powinniśmy być lepsi.

$\mathrm{Z}$ dumą i dużą radością informuję Państwa, że w roku akademickim 2012/2013 tytuł profesora uzyskało aż 11 osób. Wyrazy uznania i serdeczne gratulacje kieruję do pani profesor Bożeny Birkenfeld, pani profesor Barbary Dołęgowskiej, pani profesor Jadwigi Buczkowskiej-Radlińskiej, pana profesora Dariusza Bielickiego, pana profesora Mirosława Brykczyńskiego, pana profesora Tomasza Urasińskiego, pana profesora Grzegorza Kurzawskiego, pana profesora Jarosława Pereguda-Pogorzelskiego, pana profesora Jacka Rudnickiego, pana profesora Stanisława Zajączka oraz pana profesora Piotra Prowansa.

Uniwersytet nieustannie otwiera się na nowe środowiska. Nasze doświadczenia wskazują, że fascynacja medycyną dotyka ludzi w każdym wieku. Najmłodszy nasz „student”, uczestnik DUM PUM, ma 7 lat, natomiast najstarszy to ponad 80-letni uczestnik zainaugurowanego w dniu 13 września 2013 r. Medycznego Uniwersytetu Seniora Pomorskiego Uniwersytetu Medycznego (MUS PUM). Bardzo ważną grupą dla PUM są licealiści. To właśnie dla nich rozpoczyna się kolejna edycja projektu edukacyjnego pod nazwą MAM PUM (Młodzieżowa Akademia Medyczna Pomorskiego Uniwersytetu Medycznego w Szczecinie). Pracujemy obecnie nad formułą oferty edukacyjnej adresowanej do uczniów gimnazjów. $\mathrm{Z}$ tego miejsca panu prezydentowi Piotrowi Krzystkowi składam serdeczne podziękowanie za wsparcie finansowe udzielane nam przez Miasto Szczecin, bez którego nie byłaby możliwa realizacja tych projektów.

Doktor Edward Drescher, jeden z naszych ojców założycieli, tak opisał pierwsze lata uczelni: „W wielu dyscyplinach Akademia była wręcz monopolistą, poza nią nie istniały na terenie miasta placówki specjalistyczne. Było to zjawisko niespotykane $\mathrm{w}$ innych ośrodkach akademickich. Zamiast skoncentrować swe wysiłki na problemach dydaktycznych i naukowych - kliniki PAM pełniły permanentne dyżury dla rozrastającego się miasta, a nawet województwa, stały się szpitalami powszechnymi. W czasie gdy inne, prawidłowo zorganizowane akademie medyczne koncentrowały się na problemach nauczania, rozwijania badań naukowych i tworzenia klinik wysoce wyspecjalizowanych - szczecińscy pracownicy kliniczni w ciężkim, codziennym trudzie walczyli o zdrowie ludności". Jak widać, działalność lecznicza na rzecz społeczności lokalnej to od samego początku znak szczególny i trwały wyróżnik naszej uczelni, który w aktualnej sytuacji prawnej realizowany jest poprzez oba szpitale uniwersyteckie zatrudniające ponad 2600 osób i działającą od roku w formule spółki z o.o. Uniwersytecką Klinikę Stomatologiczną. Jest jeszcze jeden, mam nadzieję równie trwały wyróżnik działalności naszych podmiotów prowadzących działalność leczniczą: dodatni wynik finansowy. Dlatego też pani prezes dr Iwonie Chruściel-Malinowskiej, pani dyrektor dr Marii Ilnickiej-Mądry i pani dyrektor dr Barbarze Turkiewicz składam podziękowania dla kierowanych przez nie zespołów za trud i dobrą pracę na rzecz zdrowia powierzonych im chorych Gdy dodam, iż od 1 stycznia br. kanclerzem PUM jest pani mgr Maria Czerniecka, to nie pozostaje mi nic innego, jak przywołać trafny aforyzm Margaret Thatcher: ,Jeśli chcesz, by coś zostało powiedziane - powierz to mężczyźnie. Jeśli chcesz, by zostało zrobione - powierz to kobiecie".

$\mathrm{Z}$ tego miejsca chcę wszystkim Państwu podziękować za wysiłek i czas poświęcony dla dobra naszej instytucji. Pomorski Uniwersytet Medyczny w Szczecinie to przede wszystkim wyjątkowi otwarci ludzie, pełni entuzjazmu i pasji do działania. Na naszym Uniwersytecie pracuje 1086 osób, w tym 628 nauczycieli akademickich, wśród nich 85 z tytułem profesora i 71 ze stopniem naukowym doktora habilitowanego. Dziękuję z tego miejsca każdemu pracownikowi za codzienny trud i zaangażowanie na rzecz PUM, za ten swoisty etos i poczucie dumy z udziału w rozwoju Uniwersytetu. Pragnę złożyć szczególne podziękowania pani profesor Krystynie Lisieckiej-Opalko, która w tym roku przechodzi na emeryturę. Żegnają się z nami także Koleżanki i Koledzy spoza grona nauczycieli. Szanowni Państwo, pamiętajcie, że to jest nadal wasza uczelnia. Wyrazy współczucia kieruję do bliskich śp. Danuty Bereszko i profesora Ignacego Urasińskiego, którzy tworzyli historię Pomorskiego Uniwersytetu Medycznego w Szczecinie, a odeszli w ostatnim roku ku wieczności. Zachowajmy również w pamięci naszych zmarłych studentów: panią Sylwię Kuć i pana Michaela Stasiaka. Uczcijmy ich chwilą ciszy.

Za nami pierwszy rok kadencji 2012-2016. Przychodzą mi tutaj na myśl słowa naszego wieszcza: „O roku ów! Kto ciebie widział w naszym kraju!”. Tak, to był bez wątpienia rok bogaty w wydarzenia, które wpisują się w życie naszej uczelni. Przypomnę choć kilka najważniejszych: powołanie Zachodniopomorskiego Centrum Biogospodarki, konsorcjum, w którego skład weszły: Pomorski Uniwersytet Medyczny w Szczecinie, Zachodniopomorski Uniwersytet Technologiczny w Szczecinie, Uniwersytet Szczeciński, Politechnika Koszalińska i Urząd Marszałkowski Województwa Zachodniopomorskiego. PUM został zaproszony przez Bank Zachodni WBK do międzynarodowej sieci uczelni partnerskich Santander Universidades, do której należy ponad tysiąc szkół wyższych na świecie, w tym Uniwersytet Harvarda oraz uniwersytety w Oxfordzie i Cambridge. Identyfikacja dotąd bezimiennych żołnierzy podziemia niepodległościowego, zamordowanych po 1945 r. w więzieniu na Mokotowie i ekshumowanych z kwatery „E” na Powązkach, dokona- 
na przez utworzoną na mocy porozumienia PUM i IPN Polską Bazę Genetyczną Ofiar Totalitaryzmów, to ważne osiągnięcie naukowe o dużym pozytywnym wydźwięku humanitarnym, społecznym i historycznym. W kwietniu odwiedziła nas pani rektor Uniwersytetu w Greifswaldzie. Ta historyczna wizyta 352. rektora z bliskiego nam nie tylko geograficznie Greifswaldu nadała nowy wymiar współpracy transgranicznej między naszymi uczelniami, w tym zwłaszcza w realizowanym $w$ ramach INTERREG IV A projekcie badań przesiewowych noworodków. W maju wraz z panem dziekanem Leszkiem Domańskim miałem zaszczyt przedstawienia panu Joachimowi Gauckowi, prezydentowi Niemiec, osiągnięć realizowanego wraz z partnerami niemieckimi projektu „Telemedycyna w Euroregionie Pomerania”.

Oczekujemy, że jeszcze w tym roku zakończone zostaną dwie inwestycje uczelni: Międzywydziałowe Centrum Dydaktyki i Centrum Diagnostyki i Leczenia Nowotworów Dziedzicznych, które w 2014 r. w istotny sposób wzmocnią działalność dydaktyczną, naukową i leczniczą, trzy filary, na których opiera się misja Pomorskiego Uniwersytetu Medycznego w Szczecinie.

Rok akademicki 2013/2014 ogłaszam za otwarty. Quod felix, faustum fortunatumque sit! 